\title{
Crown Ethers as Building Blocks for Carbohydrate Receptors
}

\author{
Monika Mazik, Matthias Kuschel, and Willi Sicking
}

\section{Page}

1. Syntheses of the receptors $\mathbf{1}$ and 2 S2

1.1 Synthesis of the receptor $1 . \quad$ S2

1.2 Synthesis of the receptor $2 . \quad$ S3

2. ${ }^{1} \mathrm{H}$ NMR titration of $\mathbf{1}$ with $\beta$-glucopyranoside 3a (chemical shifts of the $\mathrm{CH}_{3} \quad$ S4 and the pyridine $\mathrm{CH}$ protons).

3. $\quad{ }^{1} \mathrm{H}$ NMR titration of $\mathbf{1}$ with $\alpha$-glucopyranoside $\mathbf{4 a}$ (chemical shifts of the $\mathrm{CH}_{3} \quad \mathrm{~S} 4$ and the pyridine $\mathrm{CH}$ protons).

4. $\quad{ }^{1} \mathrm{H}$ NMR titration of $\mathbf{1}$ with $\beta$ - and $\alpha$-glucopyranoside, 3a and $\mathbf{4 a}$ (typical titration S5 curves).

5. Extraction of $\beta$ - and $\alpha$-methyl-glucopyranoside (3b and $\mathbf{4 b}$ ) from the solid state into a $\mathrm{CDCl}_{3}$-solution of receptor 1 .

6. ${ }^{1} \mathrm{H}$ NMR Titration of receptor $\mathbf{2}$ with $\alpha$-glucopyranoside $\mathbf{4 a}$ (Chemical shifts of the $\mathrm{CH}_{3}$ and $\mathrm{CH}$ resonances, protons $\mathrm{C}, \mathrm{E}, \mathrm{H}$, and $\mathrm{I}$ ).

7. $\quad{ }^{1} \mathrm{H}$ NMR titration of $\mathbf{2}$ with $\alpha$-glucopyranoside $\mathbf{4 a}$ (typical titration curve and a representative mole ratio plot).

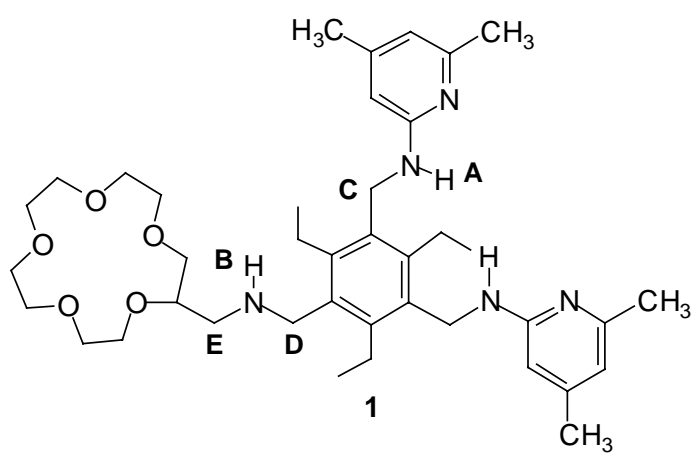<smiles></smiles> 


\section{Syntheses of the receptors 1 and 2.}

\subsection{Synthesis of the receptor 1 .}

The synthesis of 1 started from 1,3,5-tris(bromomethyl)-2,4,6-trimethyl-benzene (5), which was converted into the compound 7 via reaction with two equivalents of 2-amino-4,6dimethyl-pyridine (6), followed by the reaction with one equivalent of 2-aminomethyl-15crown-5 (8), as shown in Scheme S1.

\section{SCHEME S1}

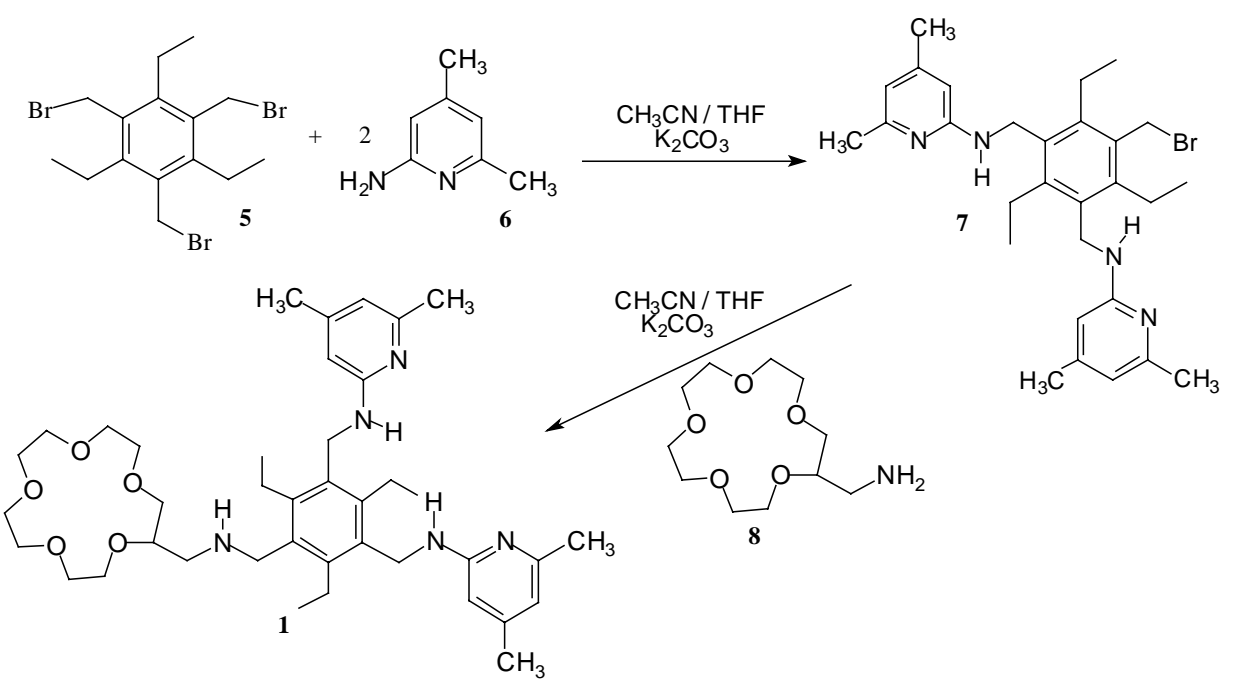

Compound 7. To a mixture of 1,3,5-tris(bromomethyl)-2,4,6-trimethyl-benzene (3.00 g, 6.80 mmol $)$ and $\mathrm{K}_{2} \mathrm{CO}_{3}(1.88 \mathrm{~g}, 13.60 \mathrm{mmol})$ in $\mathrm{CH}_{3} \mathrm{CN} / \mathrm{THF}(1: 1 \mathrm{v} / \mathrm{v} ; 40 \mathrm{~mL})$ was added dropwise a $\mathrm{CH}_{3} \mathrm{CN}(10 \mathrm{~mL})$ solution of 2-amino-4,6-dimethyl-pyridine (1.66 g, 13.60 $\mathrm{mmol}$ ). The mixture was stirred at room temperature for $72 \mathrm{~h}$. After filtration and evaporation of solvents, the crude product was purified by column chromatography (ethyl acetate/toluene, 1:3 v/v). Yield $30 \%$. M.p. $77-78{ }^{\circ} \mathrm{C}$. ${ }^{1} \mathrm{H}-\mathrm{NMR}\left(400 \mathrm{MHz}, \mathrm{CDCl}_{3}\right) \delta=1.22(\mathrm{t}, 3 \mathrm{H}, J=7.5$ Hz), 1.29 (t, 6H, J = 7.5 Hz), $2.24(\mathrm{~s}, 6 \mathrm{H}), 2.36(\mathrm{~s}, 6 \mathrm{H}), 2.73(\mathrm{q}, 2 \mathrm{H}, J=7.5 \mathrm{~Hz}), 2.85(\mathrm{q}, 4 \mathrm{H}$, $J=7.5 \mathrm{~Hz}), 4.23(\mathrm{t}, 2 \mathrm{H}, J=4.2 \mathrm{~Hz}), 4.37(\mathrm{~d}, 4 \mathrm{H}, J=4.2 \mathrm{~Hz}), 4.62(\mathrm{~s}, 2 \mathrm{H}), 6.10(\mathrm{~s}, 2 \mathrm{H}), 6.35$ (s, $2 \mathrm{H}) .{ }^{13} \mathrm{C}-\mathrm{NMR}\left(100 \mathrm{MHz}, \mathrm{CDCl}_{3}\right) \delta=16.4,16.7,21.1,22.8,23.0,24.1,29.6,40.5,103.6$, $113.9,131.9,133.4,143.8,144.9,148.9,156.5,158.0$. HR-MS calcd for $\mathrm{C}_{29} \mathrm{H}_{39} \mathrm{BrN}_{4}$ 5232.2353; found: 522.2360. $\mathrm{R}_{f=} 0.31$ (ethyl acetate/toluene, $1: 3 \mathrm{v} / \mathrm{v}$ ). 
Receptor 1. To a mixture of compound $7(262.5 \mathrm{mg}, 0.50 \mathrm{mmol})$ and $\mathrm{K}_{2} \mathrm{CO}_{3}(69.3 \mathrm{mg}, 0.50$ $\mathrm{mmol})$ in $\mathrm{CH}_{3} \mathrm{CN} / \mathrm{THF}(1: 1 \mathrm{v} / \mathrm{v} ; 20 \mathrm{~mL})$ was added dropwise a $\mathrm{CH}_{3} \mathrm{CN}(10 \mathrm{~mL})$ solution of 2aminomethyl-15-crown-5 (125 mg, $0.50 \mathrm{mmol})$.The mixture was stirred at room temperature for $48 \mathrm{~h}$. After filtration and evaporation of solvents, the crude product was purified by column chromatography (chloroform/methanol 7:1 v/v). Yield $62 \%$. M.p. $57-58{ }^{\circ} \mathrm{C} .{ }^{1} \mathrm{H}-\mathrm{NMR}$ $\left(500 \mathrm{MHz}, \mathrm{CDCl}_{3},[\mathbf{1}]=0.9 \mathrm{mM}\right) \delta=1.23(\mathrm{t}, 9 \mathrm{H}, J=7.6 \mathrm{~Hz}), 2.23(\mathrm{~s}, 6 \mathrm{H}), 2.35(\mathrm{~s}, 6 \mathrm{H})$, 2.77 (m, 7 H), 3.70 (m, 23 H), 4.25 (br. s, 2 H) 4.36 (d, 4H, J = 4.0 Hz), 6.08 (s, 2 H), 6.33 (s, $2 \mathrm{H}) .{ }^{13} \mathrm{C}-\mathrm{NMR}\left(100 \mathrm{MHz}, \mathrm{CDCl}_{3}\right) \delta=16.8,16.9,21.1,22.8,24.1,40.6,47.8,52.1,70.1$, 70.4, 70.5, 70.6, 70.8, 70.9, 71.0, 72.9, 78.7, 103.5, 113.8, 132.7, 142.9, 143.2, 148.8, 156.5, 158.2, 162.7. HR-MS calcd for $\mathrm{C}_{40} \mathrm{H}_{61} \mathrm{~N}_{5} \mathrm{O}_{5}$ 691.4667; found: 691.4671. $\mathrm{R}_{f}=0.10$ (chloroform/methanol, 7:1 v/v).

\subsection{Synthesis of the receptor 2.}

To a solution of benzene-1,3,5-tricarbonyl chloride $(187.4 \mathrm{mg}, 0.70 \mathrm{mmol})$ in dry $\mathrm{CH}_{2} \mathrm{Cl}_{2}(10$ $\mathrm{ml})$ was added a $\mathrm{CH}_{2} \mathrm{Cl}_{2}(10 \mathrm{~mL})$ solution of 4'-aminobenzo-15-crown-5 (200 mg, 0.70 mmol) and triethylamine $(0.1 \mathrm{~mL})$. The reaction mixture was stirred at room temperature for $45 \mathrm{~min}$ and then a $\mathrm{CH}_{2} \mathrm{Cl}_{2}(10 \mathrm{~mL})$ solution of 2-amino-4,6-dimethylpyridine (172.5 mg, 1.41 mmol) was added. The mixture was stirred at room temperature for $72 \mathrm{~h}$. The organic phase was washed three times with water $(3 \times 10 \mathrm{~mL})$, dried, and the solvent was evaporated. The crude product was was purified by column chromatography (chloroform/methanol 7:1 v/v). Yield $41 \%$. M.p. $200{ }^{\circ} \mathrm{C}$ (decomp.). ${ }^{1} \mathrm{H}-\mathrm{NMR}\left(500 \mathrm{MHz}, \mathrm{CDCl}_{3} ;[2]=0.9 \mathrm{mM}\right) \delta=2.38$ (s, $6 \mathrm{H}), 2.45$ (s, 6H), 3.77 (br.s, 8H), 3.92 (m, 4H), 4.16 (m, 2H), 4.21 (m, 2H), 6.82 (s, 2H), 6.90 $(\mathrm{d}, 1 \mathrm{H}, J=8.5 \mathrm{~Hz}), 7.10(\mathrm{dd}, 1 \mathrm{H}, J=8.5 / 2.2 \mathrm{~Hz}), 7.47(\mathrm{~d}, 1 \mathrm{H}, J=2.2 \mathrm{~Hz}), 7.99(\mathrm{~s}, 1 \mathrm{H}), 8.02$ $(\mathrm{s}, 2 \mathrm{H}), 8.63(\mathrm{~s}, 2 \mathrm{H}), 8.65(\mathrm{~s}, 1 \mathrm{H}), 8.67(\mathrm{~s}, 2 \mathrm{H}) .{ }^{13} \mathrm{C}-\mathrm{NMR}\left(50 \mathrm{MHz}, \mathrm{CDCl}_{3}\right) \delta=21.3,23.7$, 68.7, 69.4, 69.5, 69.6, 70.4, 70.5, 70.9, 107.3, 112.0, 113.1, 114.6, 121.0, 128.9, 129.1, 131.9, 135.4, 136.2, 149.2, 150.3, 150.4, 156.6, 163.6, 163.9. HR-MS calcd for $\mathrm{C}_{37} \mathrm{H}_{41} \mathrm{~N}_{5} \mathrm{O}_{8}$ 683.2950; found: 683.2958. $\mathrm{R}_{f=} 0.66$ (chloroform/methanol 7:1 v/v). 
2. $\quad{ }^{1} \mathrm{H}$ NMR titration of $\mathbf{1}$ with $\beta$-glucopyranoside 3a (chemical shifts of the $\mathrm{CH}_{3}$ and the pyridine $\mathrm{CH}$ protons).

a)

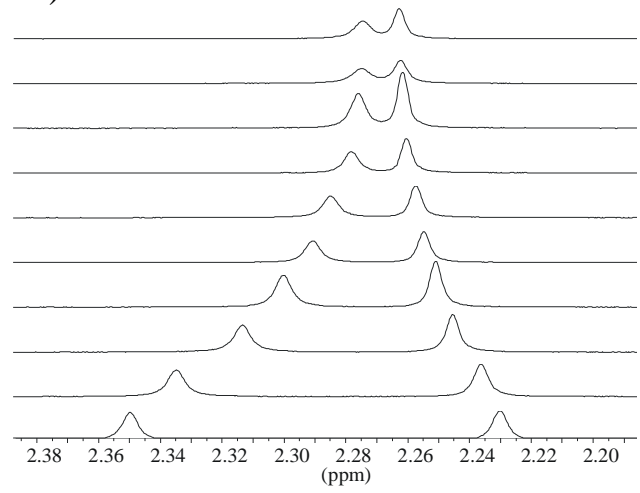

b)

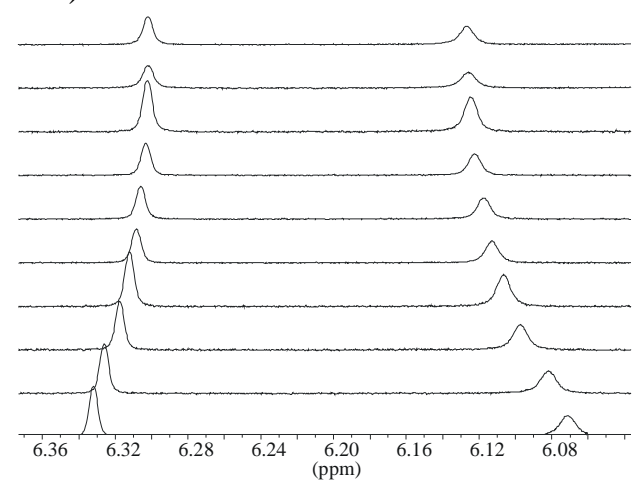

FIGURE S1. Partial ${ }^{1} \mathrm{H}$ NMR spectra $\left(500 \mathrm{MHz}, \mathrm{CDCl}_{3}, 25^{\circ} \mathrm{C}\right.$ ) of $\mathbf{1}$ after addition of (from bottom to top) $0,0.27,0.55,0.83,1.11,1.38,2.08,2.77,3.47$ and 4.16 equiv of $\mathbf{3 a}([\mathbf{1}]=0.87 \mathrm{mM})$. (a) Chemical shifts of the $\mathrm{CH}_{3}$ resonances. (b) Chemical shifts of the pyridine $\mathrm{CH}$ resonances.

3. ${ }^{1} \mathrm{H}$ NMR titration of $\mathbf{1}$ with $\alpha$-glucopyranoside $\mathbf{4 a}$ (chemical shifts of the $\mathrm{CH}_{3}$ and the pyridine $\mathrm{CH}$ protons).

a)

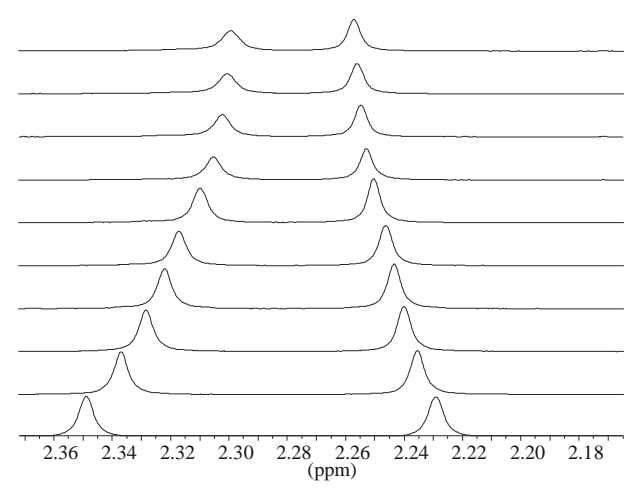

b)

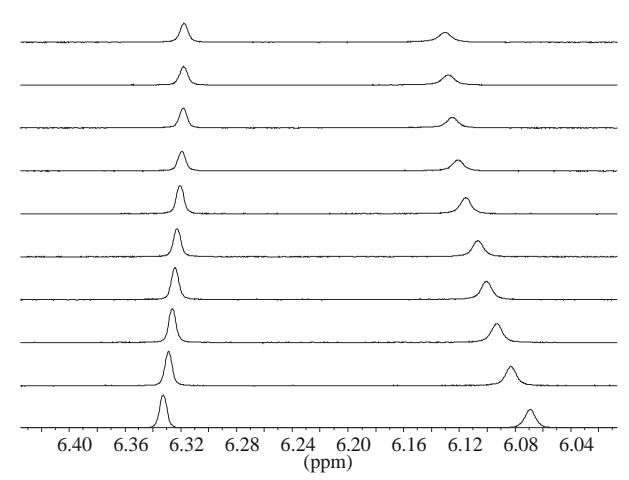

FIGURE S2. Partial ${ }^{1} \mathrm{H}$ NMR spectra $\left(500 \mathrm{MHz}, \mathrm{CDCl}_{3}, 25^{\circ} \mathrm{C}\right.$ ) of $\mathbf{1}$ after addition of (from bottom to top) $0,0.44,0.88,1.33,1.77,2.66,3.55,4.44,5.33$ and 6.22 equiv of $4 \mathbf{a}([\mathbf{1}]=0.85 \mathrm{mM})$. (a) Chemical shifts of the $\mathrm{CH}_{3}$ resonances. (b) Chemical shifts of the pyridine $\mathrm{CH}$ resonances. 
4. $\quad{ }^{1} \mathrm{H}$ NMR titration of $\mathbf{1}$ with $\beta$ - and $\alpha$-glucopyranoside, $\mathbf{3 a}$ and $\mathbf{4 a}$ (typical titration curves).

a)

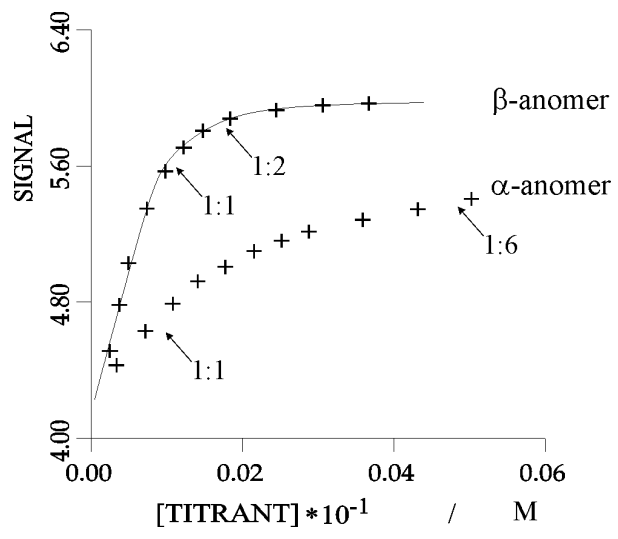

b)

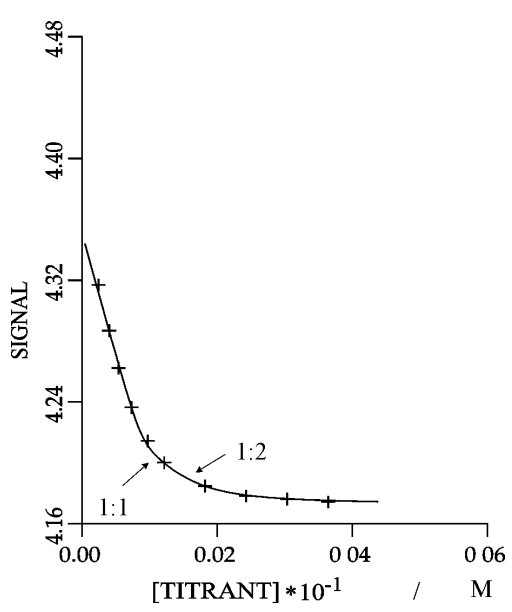

c)

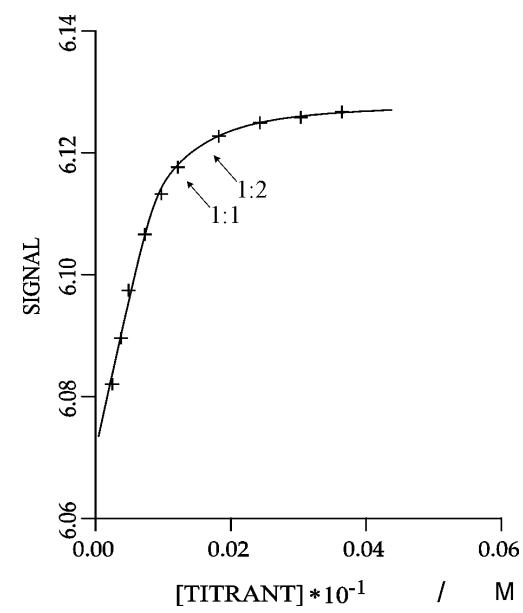

FIGURE S3. Plot of the downfield chemical shifts of the $\mathrm{NH}^{\mathrm{A}}$, resonances of $\mathbf{1}$ as a function of added $\beta$ - and $\alpha$-glucopyranoside, 3a and $\mathbf{4 a}$ (a) $([\mathbf{1}]=0.87 \mathrm{mM}$; Equiv of $\mathbf{3 a}=0.00-3.47$; Equiv of $\mathbf{4 a}=$ 0.00-6.22). Plot of the observed upfield chemical shifts of the $\mathrm{CH}_{2}{ }^{\mathrm{C}}$ (b) and downfield chemical shifts of the pyr- $\mathrm{CH}$ resonances (c) of $\mathbf{1}$ as a function of added $\beta$-glucopyranoside 3a $([\mathbf{1}]=0.87 \mathrm{mM}$; Equiv of $\mathbf{3 a}=0.00-4.18)$. The [receptor]:[sugar] ratio is marked. 
5. Extraction of $\beta$ - and $\alpha$-methyl-glucopyranoside (3b and $\mathbf{4 b}$ ) from the solid state into a $\mathrm{CDCl}_{3}$-solution of receptor $\mathbf{1}$.

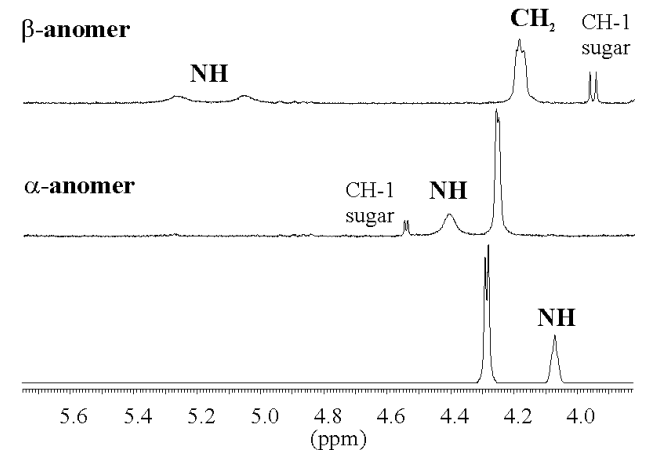

FIGURE S4. ${ }^{1} \mathrm{H}$ NMR spectra showing the $\mathrm{NH}$ and the $\mathrm{CH}_{2}$ protons of receptor 1 before and after the extraction of solid methyl- $\alpha$-glucopyranoside $\mathbf{4 b}$ or methyl- $\beta$-glucopyranoside $\mathbf{3 b}$ by a $\mathrm{CDCl}_{3}$-solution of receptor $1(0.9 \mathrm{mM})$.

$6 \quad{ }^{1}$ H NMR Titration of receptor 2 with $\alpha$-glucopyranoside $4 \mathbf{a}$ (chemical shifts of the $\mathrm{CH}_{3}$ and $\mathrm{CH}$ resonances, protons $\mathrm{C}, \mathrm{E}, \mathrm{H}$, and $\mathrm{I}$ ).

a)

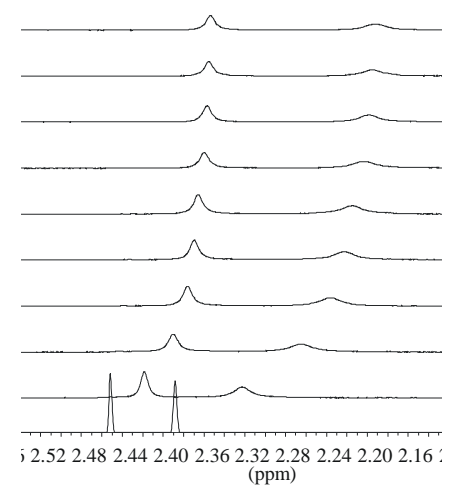

b)

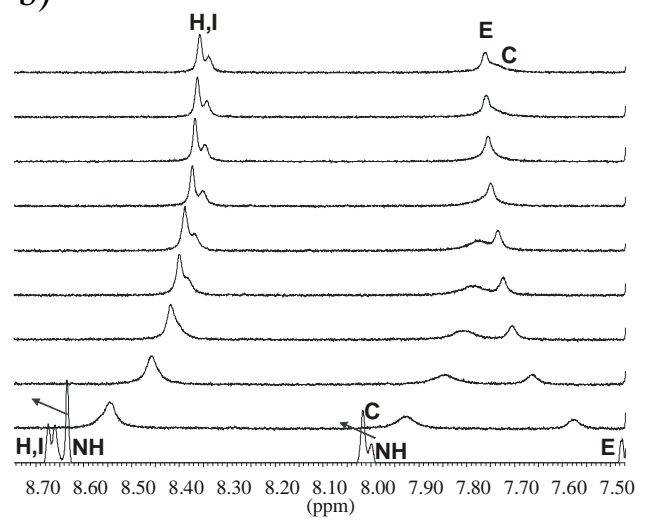

FIGURE S5. Partial ${ }^{1} \mathrm{H}$ NMR spectra $\left(500 \mathrm{MHz}, \mathrm{CDCl}_{3}, 25^{\circ} \mathrm{C}\right)$ of 2 after addition of (from bottom to top) $0,0.20,0.40,0.60,0.80,1.00,1.50,2.00,2.50$ and 3.01 equiv of $4 \mathbf{a}([\mathbf{1}]=0.87 \mathrm{mM})$. (a) Chemical shifts of the $\mathrm{CH}_{3}$ resonances. (b) Chemical shifts of the $\mathrm{CH}$ resonances, protons $\mathrm{C}, \mathrm{E}, \mathrm{H}$, and I. 
7. ${ }^{1} \mathrm{H}$ NMR titration of $\mathbf{2}$ with $\alpha$-glucopyranoside $\mathbf{4 a}$ in $\mathrm{CDCl}_{3}$ (typical titration curve and a representative mole ratio plot).

a)

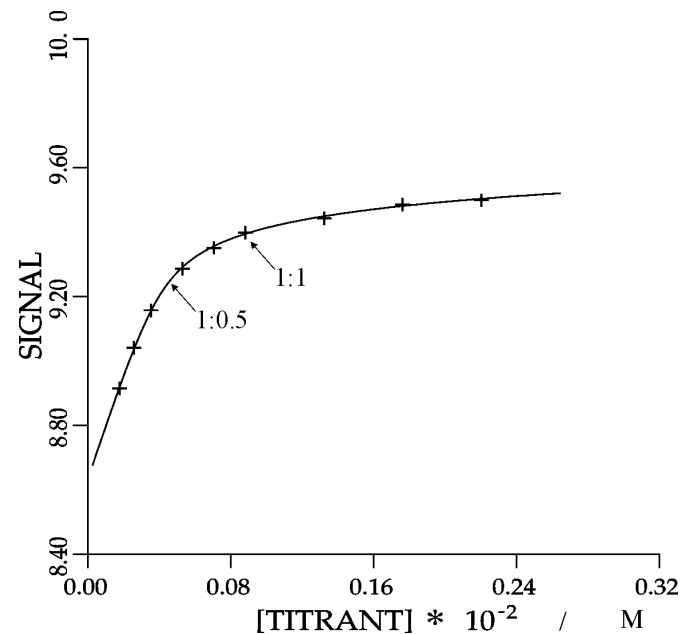

b)

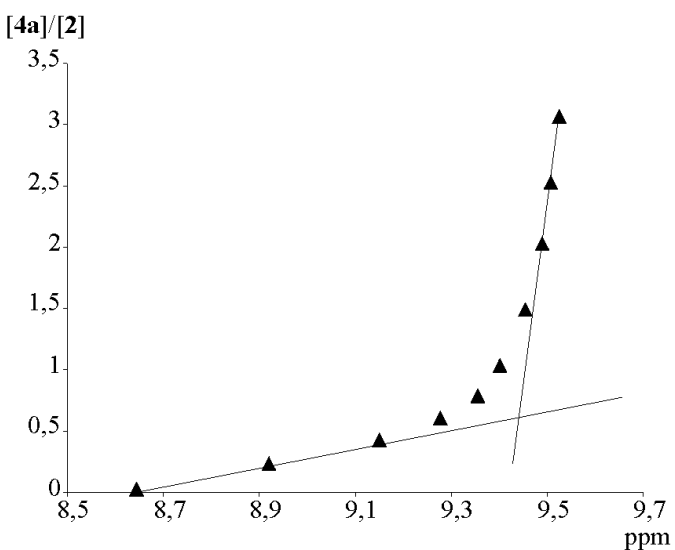

FIGURE S6. (a) Plot of the observed (x) and calculated (-) downfield chemical shifts of the $\mathrm{NH}^{\mathrm{A}}$ resonances of $\mathbf{2}$ as a function of added $\alpha$-glucopyranoside $\mathbf{4 a} ;[\mathbf{2}]=0.88 \mathrm{mM}$; Equiv of $\mathbf{4 a}=0,0.20$, $0.30,0.40,0.60,0.80,1.00,1.50,2.00,2.50$. The [receptor]:[sugar] ratio is marked. (b) Mole ratio plot (analysis of the shifts of the $\mathrm{NH}^{\mathrm{A}}$ of 2 ). 